\title{
Internships before and during COVID-19: experiences and perceptions of undergraduate interns and supervisors
}

\author{
Cecilia Woon Chien Teng, Raymond Boon Tar Lim, \\ Dana Wai Shin Chow, Suganthi Narayanasamy, Chee Hsiang Liow \\ and Jeannette Jen-Mai Lee \\ Saw Swee Hock School of Public Health, National University of Singapore, \\ Singapore, Singapore and \\ Saw Swee Hock School of Public Health, National University Health System, \\ Singapore, Singapore
}

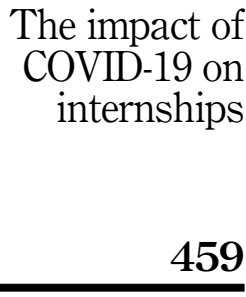

Received 27 May 2021 Revised 14 July 2021 5 August 2021

Accepted 5 August 2021

\begin{abstract}
Purpose - The COVID-19 pandemic has brought about a contingent shift to remote working and learning worldwide. However, little is known regarding the impact of this shift on internships. Moreover, much of the available literature studies on internships are focused largely on perceptions by students, less so by supervisors. This paper describes the impact of COVID-19 on public health (PH) internships and examines interns' and supervisors' perspectives on their experiences in internships before and during the pandemic.

Design/methodology/approach - A cross-sectional study design was conducted on two cohorts of undergraduate students and their supervisors in Singapore. Participants were surveyed using questionnaires with both close-ended and open-ended questions about various aspects of the internship experience. Data were triangulated from these surveys and module evaluation reports, and analyzed quantitatively and qualitatively. Findings - COVID-19 disrupted internships significantly, with a reduction in the number of placements offered and necessary changes to the internship scope. Overall, the internship experience has been positive. Supervisors and e-interns reported high levels of satisfaction and documented learning gains such as the development of technical skills and soft skills unique to remote work.

Originality/value - The study findings fill current gaps in the literature on supervisor perceptions and internship experiences during COVID-19. Recommendations are proposed to optimize e-internships, a potentially authentic workplace in the post-COVID era.
\end{abstract}

Keywords COVID-19, e-internship, Internship, Public health, Remote internship, Supervisor perception Paper type Research paper

\section{Introduction}

COVID-19 has accelerated the need for digital transformation and adoption, necessitating a shift towards telecommuting and home-based learning as part of containment and risk mitigation efforts. However, little is known regarding the impact of this shift on internships, a "high-impact educational practice" in higher education (Kuh, 2008). Internships are pedagogically founded upon experiential learning, where the learner actively creates "knowledge through direct experience that is meaningful to the student with guided reflection and analysis" (Kolb, 1984). They provide real-world contexts appropriate to

(C) Cecilia Woon Chien Teng, Raymond Boon Tar Lim, Dana Wai Shin Chow, Suganthi Narayanasamy, Chee Hsiang Liow and Jeannette Jen-Mai Lee. Published by Emerald Publishing Limited. This article is published under the Creative Commons Attribution (CC BY 4.0) licence. Anyone may reproduce, distribute, translate and create derivative works of this article (for both commercial and non-commercial purposes), subject to full attribution to the original publication and authors. The full terms of this licence maybe seen at http://creativecommons.org/licences/by/4.0/legalcode

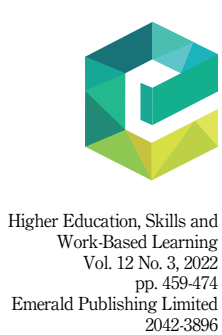

DOI 10.1108/HESWBL-05-2021-0104 
HESWBL 12,3 learners' future careers (Dewey, 1938; Yardley et al., 2012). Internships embedded within the curriculum significantly improve graduate employment rates (Silva et al., 2018) and are beneficial in reinforcing technical competencies, developing thinking skills and promoting lifelong learning (Coco, 2000; Eyler, 2009). The Institute of Medicine Committee deemed public health $(\mathrm{PH})$ training essential for a competent $\mathrm{PH}$ workforce in protecting population health, and that PH education should be accessible to all undergraduates (Gebbie et al., 2003). The accreditation framework by the Council of Education for Public Health (CEPH) includes internships, among other experiential learning activities and culminating experiences, as an integral part of the undergraduate PH curriculum (CEPH, 2016).

E-internships are computer-mediated, field-driven projects assigned to interns by external organizations where interns work online and/or remotely (Van Dorp, 2008). They emerged with the advent of information technology (IT) and the Internet and have benefitted many for whom on-site internships have posed challenges such as the need to travel long distances (Jeske and Axtell, 2014). The e-internship literature is scarce and is mostly based in the United States, the United Kingdom and Europe, specifically for primarily technologically-driven sectors (Jeske and Axtell, 2014; Massingill, 2013). The knowledge base is smaller in Asia (Jeske and Linehan, 2020; Solangi et al., 2017), including Singapore, where e-internships are relatively new. The existing e-internship literature mainly revolves around the development and implementation of e-internship models in higher education (Solangi et al., 2017; Lansu et al., 2009; Ruggiero and Boehm, 2016; Sykes and Roy, 2017) and students' experiences (Jeske and Axtell, 2014; Bugis, 2020; D'Angelo et al., 2011; Franks and Oliver, 2012; Medeiros et al., 2015; Pretti et al., 2020). Massingill (2013) described factors needed for successful e-internship collaboration between stakeholders, including benefits and limitations of e-internships, although the review was based predominantly upon online secondary data sources. The emerging literature revealed varying internship outcomes during COVID-19: many internships were either delayed, canceled, or shifted online (Bugis, 2020; Pretti et al., 2020; Aucejo et al., 2020; Briant and Crowther, 2020; Cunningham, 2020; Dani et al., 2020; Dent and White, 2020; Holt-White and Montacute, 2020; Paonessa, 2020; Salas-Provance et al., 2020; Wall, 2020). Documentation is relatively sparse regarding differences in the teaching and learning experiences in internships before and during the pandemic and supervisors' perspectives.

The Saw Swee Hock School of Public Health (SSHSPH), National University of Singapore (NUS) offers an undergraduate Minor in PH program that started in 2013 and sees its inaugural cohort under the second major program in 2021. The PH internship module is an elective under the minor program and a mandatory capstone under the second major program. When the first COVID-19 cases were reported in Singapore in January 2020, classes on-campus progressively transitioned online. As the threat of COVID-19 grew subsequently, internships had to be conducted remotely for the first time since the module's first intake in 2015. At the time of writing, subsequent waves of infections are still being reported in the world, with more workplaces and schools shifting operations including internships online (Crawford et al., 2020).

Hence, this study seeks to address gaps identified in the literature, and its objectives are to describe the impact of COVID-19 on undergraduate PH internships and examine interns' and supervisors' perspectives on teaching and learning experiences in internships before and during the pandemic.

\section{Methods \\ Module overview}

The internship module occurs every mid-May to end-July for a minimum of $240 \mathrm{~h}$, where students intern with PH-related organizations supervised by $\mathrm{PH}$ practitioners ("supervisors"). Students are matched with organizations based on the student's ranked 
preferences, statement of intent, curriculum vitae and an interview. The module includes a pre-internship briefing, and two preparatory workshops by the NUS Centre for Future-Ready Graduates [1], a university-level career guidance and preparation unit. For assessment, besides weekly reflections and attendance, interns undergo two rounds of evaluation (midterm and final evaluation) with their workplace supervisors, using supervisor evaluation surveys described below; the evaluation of the module only used data from the final supervisor evaluation survey. The module is graded on a satisfactory/unsatisfactory basis, with "Satisfactory" being awarded to students who meet the internship requirements to the satisfaction of supervisors and faculty module coordinators.

\section{Module evaluation}

Data were collected for two consecutive runs of the module (from end-July to early-August 2019 and 2020). Module evaluation was based on four data sources: two evaluation surveys respectively targeted at students and supervisors, module evaluation surveys and internship enrollment information from the learning management system (LMS). These were developed based on faculty members' and PH industry stakeholders' inputs. At the end of the internship, evaluation surveys were emailed to all supervisors and enrolled students, and module evaluation surveys were administered to students through the LMS. Participation was voluntary, save for the 2020 supervisor evaluation surveys. The SSHSPH departmental ethics review committee approved the study (SSHSPH-045).

\section{Student evaluation surveys}

Surveys for both cohorts comprised of a 13-item, five-point Likert scale (with higher values indicating greater satisfaction and "good" as the mid-point) questionnaire on internship organization (site appropriateness, suitability of atmosphere for learning, orientation, resource provision), supervisor characteristics ( $\mathrm{PH}$ skill and knowledge, dependability, adequacy of time spent with intern and provision of feedback) and experience (extent to which internship contributed to student's knowledge of $\mathrm{PH}$ organizations and skills, employment opportunity, internship value to long-term career goals, and whether the experience was enjoyable) with five additional open-ended questions for qualitative insights. Two Likert-type and four open-ended questions on demographics and areas identified to be important in e-internships (Jeske and Axtell, 2019) - (1) extent and level of satisfaction regarding communication between intern, supervisor and co-workers, (2) supervision quality, (3) skills development, (4) benefits and challenges of e-internships, (5) how learning was affected by telecommuting and (6) areas of improvement at internship organization and school levels - were also included in the 2020 survey.

\section{Supervisor evaluation surveys}

Surveys for both cohorts comprised of a 10-item, five-point Likert-scale questionnaire related to professionalism, interpersonal and communication skills, work-related knowledge and skills, and overall performance, and open-ended questions on intern's strengths and areas of improvement, skills development, and whether internship goals were met. Questions on supervisor demographics and important areas in learning in e-internships were included in the 2020 survey.

\section{Module evaluation surveys}

These surveys included Likert-type questions on students' opinion of the module, expected performance and open-ended questions on what students liked and disliked about the module.
The impact of

COVID-19 on internships 
HESWBL 12,3
Information from LMS

Aggregate details on interns' primary major, gender, year of study and internship site were obtained.

\section{Data analysis}

Descriptive statistics were used to summarize demographic characteristics and survey responses. Chi-square and Fisher's exact tests were conducted. Duplicate responses for additional questions regarding e-internships by supervisors were excluded for analysis. Only similar items between 2019 and 2020 were included for analysis. A p-value of less than 0.05 was considered statistically significant. Quantitative data analysis was conducted using Statistical Package for Social Sciences version 26.0 (Armonk, NY).

Qualitative responses were transcribed and analyzed independently by the first three authors using thematic analysis (Braun and Clarke, 2006). Specifically, the inductive process entailed familiarization with transcripts, coding, re-coding and identification of themes related to the research questions. The themes were cross-checked, reviewed and agreed upon among the first three authors. Any discrepancy was resolved by consensus. Representative quotes were extracted from the transcripts to illustrate the themes.

Data from the module evaluation surveys, student and supervisor evaluation surveys and information from the LMS were triangulated to ensure comprehensiveness and robustness of accounts.

\section{Results}

In total, 17 (94.4\% response rate) supervisors and 31 students (88.6\% response rate) participated in the evaluation surveys in 2019. For 2020, this was 21 (100\% response rate) supervisors and 26 students (72.2\% response rate). The 2019 supervisor evaluation survey was used by two supervisors in 2020, resulting in two less responses for the additional section on learning in e-internships. Interns were attached to various PH sectors: academia (SSHSPH) $(37.1 \%$ in $2019,52.8 \%$ in 2020$)$, government ministry/agency $(2.9 \%, 5.6 \%)$, nongovernmental organization (NGO) $(17.1 \%, 25.0 \%)$, private organization $(8.6 \%, 2.8 \%)$ and healthcare institution/cluster $(34.3 \%, 13.9 \%)$. Supervisors were mid-to senior-level PH professionals e.g. managers, research fellows, assistant/associate professors, executive directors. The supervisor-student ratio was mostly either 1:1, 1:2, or 1:3 save for two supervisors with six students each in 2019 and two supervisors with four students each in 2020. While most interns were in third-year students $(75-77 \%)$ and read primary majors in the life sciences (77-83\%), the module also attracted students from other majors (Table 1).

From the module evaluation surveys, more than $85 \%$ of students in both cohorts gave a "Good" or "Excellent" rating. The distribution of module ratings between the two cohorts was not significantly different $(p=0.180)$.

\section{Impact of COVID-19 on internships}

There were more internship placements initially secured prior to the lockdown-synonymous Circuit Breaker (CB) phase. Due to COVID-19, 15 placements initially offered by three government agencies and a regional healthcare cluster had to be rescinded in March 2020 by host organizations. Existing internship collaborations with four healthcare institutions and an NGO were unable to proceed since healthcare institutions were considered high-risk areas. Overseas internships were suspended due to travel restrictions. Many academics stepped in to offer more placements to meet student demands.

While all but one supervisor indicated that internship goals were met, change(s) in job scope were made in 20 placements $(55.6 \%)$ during the $\mathrm{CB}$, with the implementation of 


\begin{tabular}{|c|c|c|c|c|c|}
\hline & \multicolumn{2}{|c|}{2019} & \multicolumn{2}{|c|}{2020} & \multirow{3}{*}{$\begin{array}{l}\text { The impact of } \\
\text { COVID-19 on } \\
\text { internships }\end{array}$} \\
\hline & Frequency & $\%$ & Frequency & $\%$ & \\
\hline Total number of interns & 35 & 100.0 & 36 & 100.0 & \\
\hline $\begin{array}{l}\text { Sex } \\
\text { Female }\end{array}$ & 24 & 68.6 & 28 & 77.8 & \\
\hline $\begin{array}{l}\text { Year of study } \\
\text { Year } 2 \\
\text { Year } 3\end{array}$ & $\begin{array}{r}8 \\
27\end{array}$ & $\begin{array}{l}22.9 \\
77.1\end{array}$ & $\begin{array}{r}9 \\
27\end{array}$ & $\begin{array}{l}25.0 \\
75.0\end{array}$ & 463 \\
\hline $\begin{array}{l}\text { Primary major } \\
\text { Life sciences } \\
\text { Statistics, applied math } \\
\text { Psychology } \\
\text { Economics } \\
\text { Business } \\
\text { Biomedical engineering } \\
\text { Geography }\end{array}$ & $\begin{array}{r}27 \\
2 \\
2 \\
1 \\
1 \\
0 \\
0\end{array}$ & $\begin{array}{r}81.8 \\
6.1 \\
6.1 \\
3.0 \\
3.0 \\
0 \\
0\end{array}$ & $\begin{array}{r}30 \\
1 \\
0 \\
1 \\
1 \\
2 \\
1\end{array}$ & $\begin{array}{c}83.3 \\
2.8 \\
0 \\
2.8 \\
2.8 \\
5.6 \\
2.8\end{array}$ & $\begin{array}{r}\text { Table } 1 . \\
\text { Intern demographics }\end{array}$ \\
\hline
\end{tabular}

measures which entailed social distancing restrictions and work-from-home arrangements. Suspended PH activities included fieldwork, interaction with study participants, traveling to global offices and events typically conducted in public settings. Internships involving global health work (which tend to be done remotely by nature) and desk-bound research were relatively undisrupted.

\section{Student and supervisor perceptions on internships before and during COVID-19}

Table 2 shows the distribution of responses for Likert-type items from student evaluation surveys in 2019 and 2020. All items had a high median score of at least 4 in both cohorts. This corroborated with qualitative feedback from the module evaluation surveys where the handson PH field exposure was the prominent theme of what students liked about the module. There were, however, significant differences in the distribution of responses for six items, which had higher ratings in 2020. Consistent with the findings on supervision quality, interns provided positive feedback on their supervisors in both cohorts. Supervisors were supportive: "Not only was (my supervisor) knowledgeable, he was very approachable. Anytime I needed help, he never hesitated to help!" (Third-year life sciences, female, on-site); "I had a supportive supervisor and colleague who constantly checked in with me and ensured that the internship experience was maximized given the work-from-home situation" (Third-year life sciences, female, e-intern).

E-interns were more satisfied with supervisor dependability and availability and time spent in supervision. Comments regarding supervisor unavailability in 2019 were not seen in 2020. As teleconferencing has replaced on-site meetings, the need to commute is removed; video/phone calls, text messaging and emails have become standard modes of communication in remote work, supervisors are more accessible to e-interns. The e-internship experience was more enjoyable overall, likely due to increased flexibility, autonomy and the level of supervisory support provided: "Pleasant experience with flexible deadlines and helpful supervisor who answers all my doubts and give (sic) me sufficient space and opportunity to contribute" (Third-year statistics, male).

From the supervisor evaluation surveys, all items had a high median score of at least 4 in both cohorts. There were significant differences in the distribution of responses for six items, which had higher satisfaction ratings in 2020 (Table 3). Further analysis after removing data from the supervisors of six students in 2019 did not affect the finding. 


\section{HESWBL 12,3}

\section{4}

Table 2.

Distribution of responses (as percentages) in student evaluation surveys

\begin{tabular}{|c|c|c|c|c|c|c|c|}
\hline Criteria & & $\begin{array}{c}1 \\
\text { Poor }\end{array}$ & 2 & 3 & 4 & $\begin{array}{c}5 \\
\text { Excellent }\end{array}$ & $p$-value \\
\hline $\begin{array}{l}\text { Organization is an appropriate site of } \\
\text { internship experience }\end{array}$ & $\begin{array}{l}2019 \\
2020\end{array}$ & $\begin{array}{l}3.2 \\
0\end{array}$ & $\begin{array}{l}0 \\
0\end{array}$ & $\begin{array}{c}29.0 \\
0\end{array}$ & $\begin{array}{l}41.9 \\
46.2\end{array}$ & $\begin{array}{l}25.8 \\
53.8\end{array}$ & $0.004 *$ \\
\hline $\begin{array}{l}\text { Organization provided an atmosphere suitable } \\
\text { for learning }\end{array}$ & $\begin{array}{l}2019 \\
2020\end{array}$ & $\begin{array}{l}0 \\
0\end{array}$ & $\begin{array}{l}0 \\
0\end{array}$ & $\begin{array}{r}29.0 \\
7.7\end{array}$ & $\begin{array}{l}38.7 \\
38.5\end{array}$ & $\begin{array}{l}32.3 \\
53.8\end{array}$ & 0.086 \\
\hline $\begin{array}{l}\text { Organization provided orientation and/or } \\
\text { explained policies and procedures }\end{array}$ & $\begin{array}{l}2019 \\
2020\end{array}$ & $\begin{array}{l}0 \\
3.8\end{array}$ & $\begin{array}{l}6.50 \\
3.8\end{array}$ & $\begin{array}{r}29.0 \\
3.8\end{array}$ & $\begin{array}{l}38.7 \\
34.6\end{array}$ & $\begin{array}{l}25.8 \\
53.8\end{array}$ & $0.026^{*}$ \\
\hline $\begin{array}{l}\text { Organization provided adequate resources to } \\
\text { complete work assignment }\end{array}$ & $\begin{array}{l}2019 \\
2020\end{array}$ & $\begin{array}{l}0 \\
0\end{array}$ & $\begin{array}{l}0 \\
3.8\end{array}$ & $\begin{array}{l}16.1 \\
11.5\end{array}$ & $\begin{array}{l}61.3 \\
30.8\end{array}$ & $\begin{array}{l}22.6 \\
53.8\end{array}$ & $0.033^{*}$ \\
\hline $\begin{array}{l}\text { Supervisor was knowledgeable and skilled in } \\
\mathrm{PH} \text { practices }\end{array}$ & $\begin{array}{l}2019 \\
2020\end{array}$ & $\begin{array}{l}0 \\
0\end{array}$ & $\begin{array}{l}3.2 \\
0\end{array}$ & $\begin{array}{l}0 \\
3.8\end{array}$ & $\begin{array}{l}38.7 \\
23.1\end{array}$ & $\begin{array}{l}58.1 \\
73.1\end{array}$ & 0.281 \\
\hline $\begin{array}{l}\text { Supervisor was dependable and available to } \\
\text { assist when needed }\end{array}$ & $\begin{array}{l}2019 \\
2020\end{array}$ & $\begin{array}{l}0 \\
0\end{array}$ & $\begin{array}{l}0 \\
0\end{array}$ & $\begin{array}{c}16.1 \\
0\end{array}$ & $\begin{array}{l}54.8 \\
23.1\end{array}$ & $\begin{array}{l}29.0 \\
76.9\end{array}$ & $0.001 *$ \\
\hline $\begin{array}{l}\text { Supervisor spent an adequate amount of time } \\
\text { with student }\end{array}$ & $\begin{array}{l}2019 \\
2020\end{array}$ & $\begin{array}{l}3.2 \\
0\end{array}$ & $\begin{array}{l}0 \\
3.8\end{array}$ & $\begin{array}{r}32.3 \\
7.7\end{array}$ & $\begin{array}{l}45.2 \\
30.8\end{array}$ & $\begin{array}{l}19.4 \\
57.7\end{array}$ & $0.006^{*}$ \\
\hline $\begin{array}{l}\text { Supervisor provided constructive feedback on } \\
\text { my work activities }\end{array}$ & $\begin{array}{l}2019 \\
2020\end{array}$ & $\begin{array}{l}0 \\
0\end{array}$ & $\begin{array}{l}9.7 \\
0\end{array}$ & $\begin{array}{r}12.9 \\
3.8\end{array}$ & $\begin{array}{l}45.2 \\
34.6\end{array}$ & $\begin{array}{l}32.3 \\
61.5\end{array}$ & 0.081 \\
\hline $\begin{array}{l}\text { Experience improved student's knowledge of } \\
\mathrm{PH} \text { organizations/programs }\end{array}$ & $\begin{array}{l}2019 \\
2020\end{array}$ & $\begin{array}{l}0 \\
0\end{array}$ & $\begin{array}{l}6.5 \\
0\end{array}$ & $\begin{array}{r}19.4 \\
7.7\end{array}$ & $\begin{array}{l}45.2 \\
38.5\end{array}$ & $\begin{array}{l}29.0 \\
53.8\end{array}$ & 0.153 \\
\hline $\begin{array}{l}\text { Daily tasks contributed to student knowledge } \\
\text { and/or skills }\end{array}$ & $\begin{array}{l}2019 \\
2020\end{array}$ & $\begin{array}{l}3.2 \\
0\end{array}$ & $\begin{array}{l}9.7 \\
0\end{array}$ & $\begin{array}{l}29.0 \\
11.5\end{array}$ & $\begin{array}{l}35.5 \\
46.2\end{array}$ & $\begin{array}{l}22.6 \\
42.3\end{array}$ & 0.092 \\
\hline $\begin{array}{l}\text { Experience created opportunity for potential } \\
\text { employment }\end{array}$ & $\begin{array}{l}2019 \\
2020\end{array}$ & $\begin{array}{l}3.2 \\
0\end{array}$ & $\begin{array}{r}16.1 \\
7.7\end{array}$ & $\begin{array}{l}32.3 \\
30.8\end{array}$ & $\begin{array}{l}25.8 \\
34.6\end{array}$ & $\begin{array}{l}22.6 \\
26.9\end{array}$ & 0.811 \\
\hline $\begin{array}{l}\text { Experience was valuable to student long-term } \\
\text { career goals }\end{array}$ & $\begin{array}{l}2019 \\
2020\end{array}$ & $\begin{array}{l}6.5 \\
0\end{array}$ & $\begin{array}{l}0 \\
0\end{array}$ & $\begin{array}{l}29.0 \\
19.2\end{array}$ & $\begin{array}{l}45.2 \\
42.3\end{array}$ & $\begin{array}{l}19.4 \\
38.5\end{array}$ & 0.300 \\
\hline Experience was enjoyable & $\begin{array}{l}2019 \\
2020\end{array}$ & $\begin{array}{l}0 \\
0\end{array}$ & $\begin{array}{l}6.5 \\
0\end{array}$ & $\begin{array}{r}25.8 \\
3.8\end{array}$ & $\begin{array}{l}48.4 \\
38.5\end{array}$ & $\begin{array}{l}19.4 \\
57.7\end{array}$ & $0.005^{*}$ \\
\hline
\end{tabular}

\section{Student and supervisor perceptions of e-internships}

The extent and quality of virtual communication and remote supervision in 2020 were explored (Figure 1). Most supervisors and e-interns were satisfied with the virtual communication, and many e-interns contributed outside of their scope. More supervisors were less satisfied with the quality of supervision than students $(p=0.018)$ (Figure 1d). There was, however, no significant association between perceptions on supervision quality and communication quality in both student and supervisor surveys $(\phi>0.05)$. Supervisors who expressed satisfaction remarked that communication was mostly done via both synchronous and asynchronous platforms i.e. Zoom, WhatsApp, email. Those who were less satisfied indicated that communication was mostly impersonal (e.g. mainly via email), or that bandwidth issues prevented regular follow-up with e-interns. Supervisors acknowledged difficulty in providing close supervision due to the remote working arrangements and in 


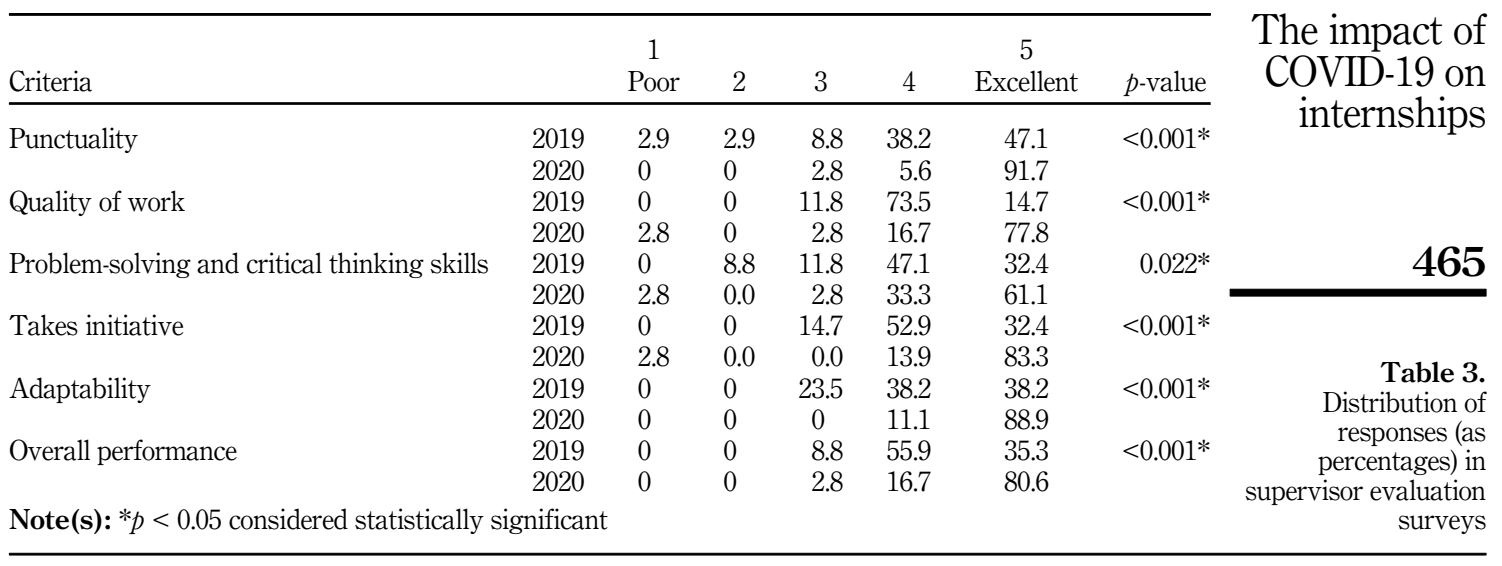

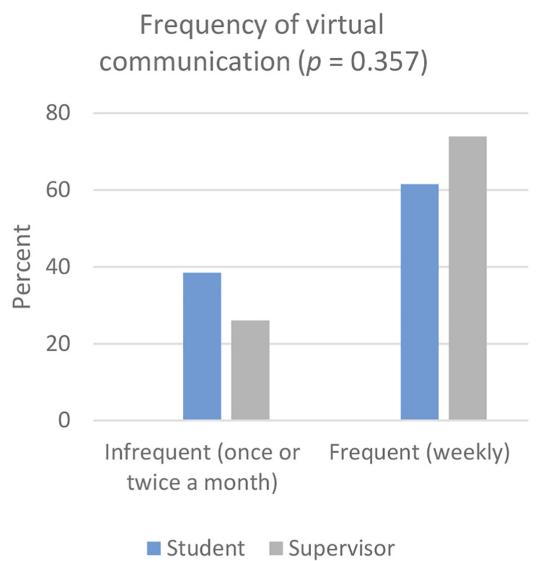

(a)
Satisfaction of intern-supervisor communication $(p=0.201)$

80

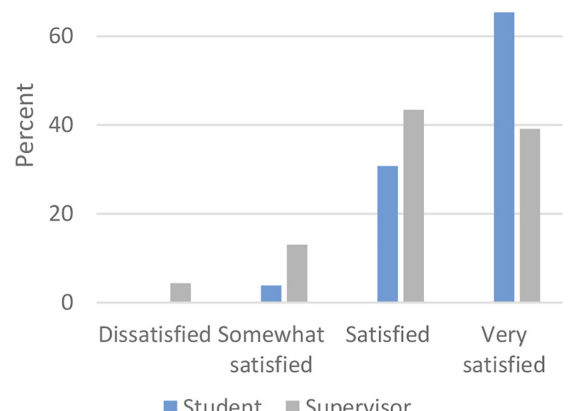

(c)
Frequency of contribution by intern

outside of internship scope $(p=0.620)$

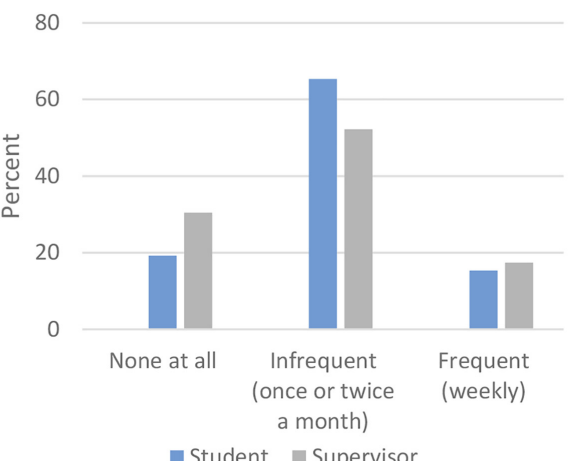

(b)

Satisfaction regarding quality of supervision $(\boldsymbol{p}=\mathbf{0 . 0 1 8})$

60

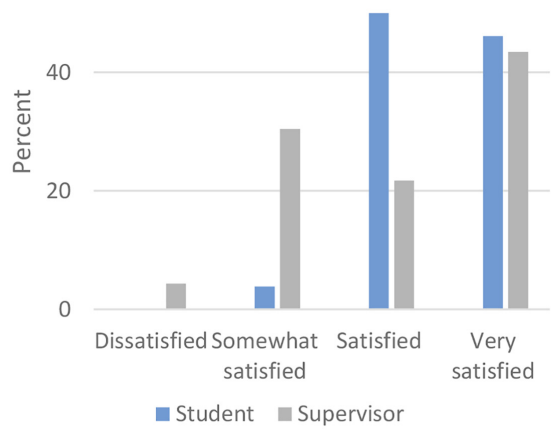

(d)
Figure 1. Distribution of responses from interns and supervisors in 2020 on the (a) frequency of virtual communication, (b) contribution of intern outside of assigned scope, satisfaction towards (c) internsupervisor communication, and (d) supervision quality 
HESWBL 12,3 exposing students to the actual working environment: "Without being in the same office space with the interns, it was difficult to have casual impromptu chats, to read body language and facial cues, and have immediate prompts in order to check in on them, find out how they are handling the work, and to give and receive feedback" (Senior Research Fellow, academia). Overall, supervisors recognized the need to provide closer guidance in the form of frequent meetings to compensate for reduced communication in e-internships, but also suggested that interns should be proactive in reaching out to them.

E-interns frequently raised issues about inadequate feedback: "I guess it is always more efficient and clearer to learn from someone in real life rather than by following instructions through email" (Third-year life sciences, female). For a few interns in 2019 who considered the on-site supervision inadequate, their main reasons were: difficulty reaching the supervisor, inadequate communication, or a mismatch in intern-supervisor expectations: " $X$ is a very knowledgeable supervisor in his field of work, however he is often not around due to his workload. When he is giving a lecture to provide us with some basic background into the relevant subject matter we are dealing with, his lectures may tend to be inadequate to get students to do the required assignments, e.g. data analysis" (Third-year life sciences, female).

Teleconferencing was helpful for interns in learning technical skills: "(I) was a bit unsure of certain things in the beginning as instructions were without demonstration but after zoom meeting, the doubts were cleared" (Third-year life sciences, female). Most interns felt somewhat connected with other co-workers (mean rating score 1.36 out of 3 ).

Pros, cons and skills development: on-site vs e-internships

The benefits and challenges of on-site and e-internships are shown in Table 4. Skills developed from on-site internships fell into four main themes: technical skills (e.g. data analyses, literature review and report writing), soft skills (e.g. interpersonal skills, public speaking and adaptability), thinking skills (e.g. critical thinking, creativity and strategy) and management skills (e.g. time/project management and leadership). E-interns developed both technical and soft skills, although e-internships appeared to be less able to develop traditional soft skills (e.g. public speaking, interpersonal communication, networking, teamwork and collaborative skills). In total, 11 of 26 e-interns $(42.3 \%)$ reported having developed communication, presentation, or related skills, whereas 16 e-interns $(61.5 \%)$ mentioned that teamwork, interpersonal or verbal communication skills were not developed during the e-internship.

The gains in soft skills were highlighted to a greater extent by interns than supervisors in 2020. Many of these skills were more unique to remote work (i.e. setting realistic deadlines, self-discipline and time management) amongst others (i.e. idea-pitching, meticulousness and confidence in expressing feedback), rather than the aforementioned traditional soft skills. Generally, research-based interns were better able to develop technical skills, whereas interns with more people-facing roles were better able to develop presentation/communication skills.

\section{Discussion}

This study describes the impact of COVID-19 on undergraduate PH internships in Singapore and explores interns' and supervisors' perceptions on teaching and learning experiences in internships before and during the pandemic. Overall, the internship experience has been positive for interns and supervisors, as triangulated from multiple sources. Both types of internships and supervisors were well-received by most interns, and most supervisors were satisfied with their interns' performance.

The COVID-19 pandemic brought about significant disruption. Internships at healthcare institutions in Singapore had to be canceled, as with health-related internships or clinical attachments elsewhere (Wall, 2020; Ahmed et al., 2020; La Republicca, 2020; Nowak et al., 2020). Interestingly, Bugis (2020) reported that $60.2 \%$ of health organizations (mostly PH 
On-site internships

Illustrative quotes/Remarks

Benefits

Immersive experience

Practical field exposure

Challenges

Mundane work

Time management issues

Access issues

E-internships

Benefits

Convenience, flexibility, autonomy

Supportive environment

Resource-saving

Challenges

Remote access issues relating to sensitive data

Sense of isolation/ disconnectedness

Limited PH activities

Impact on productivity/learning sciences, male

"Absences and punctuality" and analysis officer, NGO below

- Third-year statistics, male female
"The environment supported collaboration; with multiple small meeting rooms and places to discuss freely, it was comfortable working (here). We were not desk bound as well and could balance between working at the office and going on fieldwork, which was exciting." - Third-year life

Interns perceived field exposures such as interaction with migrant workers and the general community to be "meaningful, fulfilling, enlightening" experiences with "purpose"

A few interns found the work "repetitive" and "lacking in progression" Two supervisors indicated "Time management and punctuality";

“... HR could be quicker in processing new interns so that we can get a temporary staff pass for easier entry into the office!"

- Third-year life sciences, female

"Working remotely allows flexibility in terms of working hours and the intern could work according to his own schedule, as long as deliverables were met" - Research and analysis officer, NGO

"I had a supportive supervisor and colleague who constantly checked in with me and ensured that the internship experience was maximized given the work-from-home situation" - Third-year life sciences, female

"My organization had agreed to reimburse the intern for their transport cost and meals when at the office. As the whole internship was done remotely, it was at the end no cost to us for engaging an intern"-Research

"No need to find a desk" - Faculty, academia

Similar challenges as for on-site internships, plus the following themes

"Since the work dealt with sensitive data, I could not work on my personal computer and initially had to work on a company server. This was quite challenging because the server was not quite stable. This was less of an issue after the company issued me a laptop"

"It's always nice to be able to meet people in-person. It may feel lonely and less 'real' for the intern working remotely if they are not used to this way of working."--Faculty, academia

"More difficult to facilitate collaborative environment or build rapport in zoom meetings" - Faculty, academia

“... No opportunities for small talk and casual conversations with coworkers and supervisors e.g. during breaks, over lunch. Hard to get to know others better, or improve networking" - Third-year life sciences,

"I was) unable to experience the physical training sessions down at the nursing homes" - Third-year life sciences, female

"(Some) may find it difficult to handle distractions at home"-Consultant, NGO

Several interns indicated efforts made to improve "work-life balance"
The impact of COVID-19 on internships
Table 4.

Benefits and challenges of on-site and e-internships

organizations) continued with on-site internships between March to May 2020 with "limited COVID-19 restrictions" applied, citing reasons such as reduced workforce capacity, involvement of interns in COVID-19-related work, and how a virtual internship was not amenable. 
HESWBL 12,3
E-internships were rated more highly than on-site internships by interns regarding site appropriateness, atmosphere for learning and resource provision, likely because internships had to be carried out remotely and supervisors had tailored the internship scope to suit workfrom-home arrangements. E-internships were also rated more highly by interns on supervision quality and extent of enjoyment. Qualitatively, interns appreciated the support, flexibility and autonomy given by supervisors. Most e-interns had good working relationships with supervisors. The increased autonomy and the nature of remote work were shown to reduce work-related stress (Gajendran and Harrison, 2007), and stress had a negative effect on internship satisfaction (Mensah et al., 2021). These may explain why e-interns enjoyed their internship more, since common on-site work stressors (e.g. organizational access issues, lack of autonomy, tensions in work relationships) were minimized in e-internships. However, having too much autonomy may be detrimental to wellbeing, although this may be influenced by personality (Warr, 1994). Remote work challenges include procrastination, inability to concentrate, or distractions at home (Wang et al., 2020); similar difficulties were raised by a few participants in our study.

Supervisors and interns in 2020 were satisfied with the quality of virtual communication and supervision. Supervisor satisfaction regarding virtual communication was higher for e-internships where communication was mostly conducted via synchronous face-to-face and asynchronous platforms, than those through email. Moreover, face-to-face interaction is vital for sustaining interpersonal relationships in the workplace (Sias et al., 2012). From a pedagogical perspective, the choice of communication platform should be judiciously considered in online learning environments such as e-internships, since prompt, constructive feedback augments student learning (Bayerlein, 2014; Irons, 2007). The use of asynchronous tools as the main mode of communication may hinder the provision of timely or adequate feedback. Video-conferencing tools are thus recommended over emails which "lack social richness" (Allen et al., 2015; Waber, 2013).

Supervisors were more critical than interns regarding the quality of supervision provided. Andersen et al. (1997) reported a similar observation, although the program in study was conducted on-site. Supervisee perceptions of supervision quality were more greatly influenced by socio-emotional factors (e.g. being directly taught by the supervisor within a pleasant working relationship), whereas task-related elements (e.g. feedback on intern's taskrelated ability) were more important in influencing supervisor perceptions (Baker and Smith, 1988; Worthington and Roehlke, 1979). According to Baker and Smith (1988), the value that supervisees placed on different aspects of supervisory behavior may change with time: interns highly valued supervisor availability at the initial internship phase, but in the latter phase, interns also highly valued receiving feedback. It would be interesting to further explore how these factors contribute to the observed intern-supervisor differences.

Despite frequent virtual communication, e-interns felt isolated, with most of them unable to experience the actual work environment. Jeske and Axtell (2019) suggested that greater support may circumvent the sense of isolation among e-interns. Our findings indicate that such support should specifically address increasing social connectedness with the work environment. As a supervisor opined: "It is challenging given the most value-add during the internship comes, in my view, from the office interactions with the wider team and the less formal discussions and conversations that is possible onsite" (Senior Assistant Director, government ministry). The onsite environment not only provides benefits beyond building interpersonal skills; the richness of on-site work contexts is itself an avenue for knowledge application (Morcke et al., 2006). Hence, activities allowing interns to foster social exchanges, build social capital and enhance learning in the virtual workplace will have to be intentionally structured into e-internships.

Supervisors' ratings for specific intern attributes were significantly higher in 2020 . Since e-interns often work independently, e-internships may better foster soft skills e.g. selfdiscipline, time management, proactive problem-solving, which may explain the higher 
ratings for initiative and problem-solving skills. Movement restrictions during COVID-19 meant that e-interns were home-bound, eliminating travel time and reducing the likelihood to appear "late" for virtual meetings. Moreover, telecommuting focuses less on adhering to traditional work hours and more on submitting work by a set deadline. These may explain the higher supervisor ratings for punctuality. Supervisor ratings were higher for quality of work and adaptability as the internship scope was tailored to suit remote work and were mainly desk research-based, academic in nature, or involved the use of technology (e.g. social media) - skills and tasks that students are familiar with. On-site internships tend to include tasks that students are less exposed to, e.g. fieldwork, stakeholder engagement; this may have affected the quality of work in 2019. With the emphasis on e-internships, supervisors were inclined to hold more regular e-meet-ups guiding interns through tasks that may have resulted in improved quality of work. The abovementioned reasons may contribute to the higher ratings for overall performance in 2020.

However, traditional soft skills may not have been adequately developed in e-interns. While on-site internships may better facilitate the development of these skills, this skills gap has also been observed among on-site interns and fresh junior hires in $\mathrm{PH}$ and other industries (Lim et al., 2020; Stewart et al., 2016). Although the pre-internship briefing and preparatory webinars had incorporated setting of workplace expectations for interns regarding, for example, proactiveness and speaking out in the workplace, these attributes were still lacking based on supervisors' feedback from both cohorts. This observed gap in "people skills" among our interns (predominantly Singaporean Chinese) may be attributed to upstream factors such as upbringing and socialization in a "Confucianism heritage culture" (Tan, 2018) and/or issues related to specific teaching methodologies and educational systems as challenged by Tran (2013) and are not easily bridged by short-term interventions. Nevertheless, while the module fundamentally strives to inculcate a self-authored approach to learning (Magolda, 2001), shared responsibility is needed between educational institutions and workplace supervisors in providing real-world opportunities for interns to develop essential interpersonal skills (Majid et al., 2019).

Our findings are largely congruent with the literature in on-site internships and einternships (Jeske and Axtell, 2014; Massingill, 2013; Pretti et al., 2020; Crowell, 2018; Nelson et al., 2010). E-internships share similar challenges with distance learning (Ragusa, 2017) and telecommuting (Jeske and Axtell, 2014). According to Jeske and Linehan (2020), slightly more than half of e-interns reported having developed interpersonal and communication skills, and mentored e-interns reported developing these skills to a larger extent than those unmentored. There was a smaller proportion of e-interns who developed traditional soft skills in our study, suggesting the need for a more structured approach to supervision in e-internships.

Despite the challenges faced in e-internships, supervisors were keen to retain the e-talent groomed and were open to offer part-time and/or partially virtual internships. These suggest that e-internships are valued by prospective PH employers. Supervisors and e-interns reported high satisfaction levels and important learning gains. As telecommuting increases, skills sought after by employers may evolve, giving e-interns an advantage over students without prior remote work experience, as e-interns would have developed skills essential for telecommuting (e.g. self-management and virtual communication skills). Our findings support existing literature on the potential of e-internships as a viable alternative to on-site internships in supporting student learning and transition to the workplace (Jeske and Linehan, 2020; Bayerlein and Jeske, 2018).

\section{Significance and implications of study}

With COVID-19, remote worksites may soon come under the broadened definition of an "authentic workplace". Practical suggestions to optimize e-internships are proposed based on this study (Figure 2), in line with recent recommendations by Holt-White and Montacute
The impact of COVID-19 on internships 


\begin{tabular}{|c|c|c|c|}
\hline 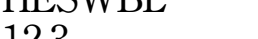 & Orientation & “Communication for learning" & Reducing isolation \\
\hline $\begin{array}{l}\text { Figure } 2 \text {. } \\
\text { Recommendations to } \\
\text { optimize e-internships }\end{array}$ & $\begin{array}{l}\text { - Internship site to continue to } \\
\text { arrange for virtual onboarding } \\
\text { - Anticipate and plan provision of } \\
\text { remote access to sensitive } \\
\text { information prior to onboarding } \\
\text { - Supervisors to formally brief } \\
\text { e-interns on assigned scope, } \\
\text { expectations, and company culture }\end{array}$ & $\begin{array}{l}\text { - Zoom? Phone call? Text? Email? } \\
\text { Judiciously consider the most } \\
\text { appropriate communication } \\
\text { platform for the discussion agenda, } \\
\text { with the aim of facilitating learning } \\
\text { - Consider regularity of meetings, } \\
\text { e.g. weekly updates with the team, } \\
\text { and one-on-one check-ins with } \\
\text { intern(s) }\end{array}$ & $\begin{array}{l}\text { - Place e- interns working on similar } \\
\text { projects in teams to provide a more } \\
\text { collaborative environment } \\
\text { - Provide interns with opportunities } \\
\text { to attend inter-departmental } \\
\text { meetings or events to get a broader } \\
\text { exposure of the organization's work } \\
\text { or network } \\
\text { - Add soft touches to foster social } \\
\text { connectedness, e.g. virtual "happy } \\
\text { hour", online birthday celebrations } \\
\text { (Pretti et al. 2020), and virtual } \\
\text { lunches }\end{array}$ \\
\hline
\end{tabular}

(2020) and Hora (2020). Further research is warranted to understand the impact of e-internships on graduate employability in a post-pandemic labor market.

\section{Study limitations}

It was not possible to measure objectively the extent of skill development because learning gains were self-reported, although this could at best be corroborated with supervisor evaluation. As many government agencies and healthcare institutions could not offer internships during the pandemic, we were unable to explore potentially unique learning gains and challenges faced by supervisors and interns from these two major PH sectors. Lastly, revisions made in the 2020 supervisor evaluation survey for improving assessment rigor precluded the analysis of some items for both cohorts. Nevertheless, the qualitative data provided rich insights in these aspects.

\section{Conclusion}

We describe the impact of COVID-19 on undergraduate $\mathrm{PH}$ internships and explore perspectives from interns and supervisors on internship experiences before and during COVID-19. Despite inherent trade-offs between e-internships and on-site internships, both were received favorably among interns and supervisors and resulted in learning gains.

\section{List of abbreviations}

$\begin{array}{ll}\text { CB } & \text { Circuit Breaker } \\ \text { CEPH } & \text { Council of Education for Public Health } \\ \text { IT } & \text { Information technology } \\ \text { LMS } & \text { Learning management system } \\ \text { NUS } & \text { National University of Singapore } \\ \text { NGO } & \text { Non-governmental organization } \\ \text { PH } & \text { Public health } \\ \text { SSHSPH } & \text { Saw Swee Hock School of Public Health }\end{array}$

\section{Note}

1. http://nus.edu.sg/CFG/ 


\section{References}

Ahmed, H., Allaf, M. and Elghazaly, H. (2020), "COVID-19 and medical education", The Lancet Infectious Diseases, Vol. 20, pp. 777-778, doi: 10.1016/S1473-3099(20)30226-7.

Allen, T.D., Golden, T.D. and Shockley, K.M. (2015), "How effective is telecommuting? Assessing the status of our scientific findings", Psychological Science in the Public Interest, Vol. 16 No. 2, pp. 40-68, doi: 10.1177/1529100615593273.

Andersen, M.B., Larson, G.A. and Luebe, J.J. (1997), "Student and supervisor perceptions of the quality of supervision in athletic training education", Journal of Athletic Training, Vol. 32 No. 4, p. 328.

Aucejo, E.M., French, J.F., Araya, M.P.U. and Zafar, B. (2020), "The impact of COVID-19 on student experiences and expectations: evidence from a survey", Journal of Public Economics, Vol. 191, 104271, doi: 10.1016/j.jpubeco.2020.104271.

Baker, D.R. and Smith, S.L. (1988), "A comparison of field faculty and field student perceptions of selected aspects of supervision”, The Clinical Supervisor, Vol. 5 No. 4, pp. 31-42, doi: 10.1300/ J001v05n04_04.

Bayerlein, L. (2014), "Students' feedback preferences: how do students react to timely and automatically generated assessment feedback?", Assessment and Evaluation in Higher Education, Vol. 39 No. 2, pp. 916-931.

Bayerlein, L. and Jeske, D. (2018), "Student learning opportunities in traditional and computer-mediated internships", Education+ Training, Vol. 60 No. 1, pp. 27-38, doi: 10.1108/ET-10-2016-0157.

Braun, V. and Clarke, V. (2006), "Using thematic analysis in psychology", Qualitative Research in Psychology, Vol. 3 No. 2, pp. 77-101.

Briant, S. and Crowther, P. (2020), "Reimagining internships through online experiences: multidisciplinary engagement for creative industries students", International Journal of WorkIntegrated Learning, Vol. 21 No. 5, pp. 617-628.

Bugis, B.A. (2020), "The impact of the COVID-19 pandemic on internship activities at health organizations in Saudi Arabia”, Hospital Topics, pp. 1-7.

Coco, M. (2000), "Internships: a try before you buy arrangement", SAM Advanced Management Journal, Vol. 65 No. 2, pp. 41-43.

Council on Education for Public Health (2016), Accreditation Criteria, Schools of Public Health Public Health Programs, Council on Education for Public Health, Silver Spring, MD.

Crawford, J., Butler-Henderson, K., Rudolph, J., Malkawi, B., Glowatz, M., Burton, R., Magni, P.A. and Lam, S. (2020), "COVID-19: 20 countries' higher education intra-period digital pedagogy responses", Journal of Applied Learning and Teaching, Vol. 3 No. 1, pp. 1-20, doi: 10.37074/jalt.2020.3.1.7.

Crowell, T.L. (2018), "Academic internships: to take or not to take? Students' assessments of public health fieldwork", Pedagogy in Health Promotion, Vol. 4 No. 1, pp. 19-34, doi: 10.1177/ 2373379916684850.

Cunningham, L.A. (2020), Adapting to Remote Law Practice through the Pandemic: Essays from the GWNY 2020 Business Lawyering Class, GWU Legal Studies Research Paper 2020-22, George Washington University Law Faculty, Washington, DC.

Dani, R., Kukreti, R., Negi, A. and Kholiya, D. (2020), "Impact of COVID-19 on education and internships of hospitality students", International Journal of Current Research and Review, Vol. 12 No. 21, p. 86.

Dent, H. and White, B.J. (2020), "Virtual internships: interdisciplinary remote work for undergraduates during a pandemic", Issues in Information Systems, Vol. 21 No. 3, pp. 11-19, doi: 10.48009/3_iis_ 2020_11-19.

Dewey, J. (1938), Experience and Education, Collier Books, New York, NY.

D'Angelo, C., Arastoopour, G., Chesler, N. and Shaffer, D.W. (2011), "Collaborating in a virtual engineering internship", paper presented at the 9th International Computer-Supported Collaborative Learning Conference, Hong Kong, 4-6 July.

The impact of

COVID-19 on internships 
HESWBL 12,3
Eyler, J. (2009), “The power of experiential education”, Liberal Education, Vol. 95 No. 4, pp. 24-31.

Franks, P.C. and Oliver, G.C. (2012), "Experiential learning and international collaboration opportunities: virtual internships”, Library Review, Vol. 61 No. 4, pp. 272-285.

Gajendran, R.S. and Harrison, D.A. (2007), "The good, the bad, and the unknown about telecommuting: meta-analysis of psychological mediators and individual consequences", Journal of Applied Psychology, Vol. 92 No. 6, p. 1524, doi: 10.1037/0021-9010.92.6.1524.

Gebbie, K., Rosenstock, L. and Hernandez, L.M. (2003), Who Will Keep the Public Healthy? Educating Public Health Professionals for the 21st Century, National Academies Press, Washington, DC.

Holt-White, E. and Montacute, R. (2020), "COVID-19 and social mobility impact brief \#5. Graduate recruitment and access to the workplace”, available at: https://dera.ioe.ac.uk/36101/1/Access-tothe-Workplace-Impact-Brief.pdf (accessed 24 November 2020).

Hora, M.T. (2020), "What to do about internships in light of the COVID-19 pandemic? A short guide to online internships for colleges, students, and employers", available at: http:/ccwt. wceruw.org/documents/CCWT_report_COVID-19\%20Internships.pdf (accessed 22 November 2020).

Irons, A. (2007), Enhancing Learning through Formative Assessment and Feedback, Routledge, Abingdon and New York.

Jeske, D. and Axtell, C.M. (2014), "E-internships: prevalence, characteristics and role of student perspectives”, Internet Research, Vol. 24 No. 4, pp. 457-473, doi: 10.1108/IntR-11-2012-0226.

Jeske, D. and Axtell, C.M. (2019), "Virtuality in e-internships: a descriptive account", Lazazzara, A., Nacamulli, R., Rossignoli, C. and Za, S. (Eds), Organizing for Digital Innovation. Lecture Notes in Information Systems and Organisation, Springer, Cham, pp. 219-233, doi:10.1007/978-3-31990500-6_17.

Jeske, D. and Linehan, C. (2020), "Mentoring and skill development in e-internships", Journal of WorkApplied Management, Vol. 12 No. 2, pp. 245-258, doi: 10.1108/JWAM-09-2019-0028.

Kolb, D.A. (1984), Experiential Learning: Experience as the Source of Learning and Development, Prentice-Hall, Englewood Cliffs, New Jersey, NJ.

Kuh, G.D. (2008), High-impact Educational Practices: what They Are, Who Has Access to Them, and Why They Matter, Association of American Colleges and Universities, Washington, DC.

La Repubblica (2020), "Coronavirus, medicine internships suspended in Bari. Students: "explain why”, [Italian], 26 February, available at: https://bari.repubblica.it/cronaca/2020/02/26/news/ coronavirus_sospesi_i_tirocini_per_gli_studenti_di_medicina_di_bari249627906.

Lansu, A., Löhr, A. and Van Dorp, K.J. (2009), "Professional development by e-learning: examples of effective e-internship models", paper presented at the M-2009 23rd ICDE World Conference on Open Learning and Distance Education, Netherlands, 9 June.

Lim, R.B.T., Teng, C.W.C., Azfar, J., Bun, D., Goh, G.J. and Lee, J.J.M. (2020), “An integrative approach to needs assessment and curriculum development of the first public health major in Singapore”, Frontiers in Public Health, Vol. 8, p. 182, doi: 10.3389/fpubh.2020.00182.

Magolda, M.B.B. (2001), “A constructivist revision of the measure of epistemological reflection”, Journal of College Student Development, Vol. 42 No. 6, pp. 520-534.

Majid, S., Eapen, C.M., Aung, E.M. and Oo, K.T. (2019), "The importance of soft skills for employability and career development: students and employers' perspectives”, IUP Journal of Soft Skills, Vol. 13 No. 4, pp. 7-39.

Massingill, R. (2013), "Creating win-win-win experiences: when do virtual internships really work?”, Paper Presented at the 2013 12th International Conference on Information Technology Based Higher Education and Training, 10-12 October, Turkey.

Medeiros, A.R., İcen, D., Morciano, E.A. and Cortesão, M. (2015), "Using virtual internships as an innovative learning technique”, paper presented at the 2015 IEEE Global Engineering Education Conference, 18-20 March, Estonia. 
Mensah, C., Azila-Gbettor, E.M., Appietu, M.E. and Agbodza, J.S. (2021), "Internship work-related stress: a comparative study between hospitality and marketing students", Journal of Hospitality and Tourism Education, Vol. 33 No. 1, pp. 29-42, doi: 10.1080/10963758.2020. 1726769.

Morcke, A.M., Wichmann-Hansen, G., Nielsen, D.G. and Eika, B. (2006), "Complex perspectives on learning objectives: stakeholders' beliefs about core objectives based on focus group interviews", Medical Education, Vol. 40 No. 7, pp. 675-681, doi: 10.1111/j.1365-2929.2006. 02509.x.

Nelson, J.A., Nichter, M. and Henriksen, R. (2010), "On-line supervision and face-to-face supervision in the counseling internship: an exploratory study of similarities and differences", Ideas and Research You Can Use, VISTAS, pp. 40-44.

Nowak, L., Krajewski, W., Kiełb, P., Śliwa, A., Zdrojowy-Wełna, A. and Zdrojowy, R. (2020), "COVID-19 and the urological practice: changes and future perspectives", Central European Journal of Urology, Vol. 73 No. 3, p. 269, doi: 10.5173/ceju.2020.0087.

Paonessa, M. (2020), "Recommendations on the extension of involuntary remote learning (May 2020)", available at: https://sites.psu.edu/das202c/files/2020/06/Megan.pdf (accessed 2 November 2020).

Pretti, T.J., Etmanski, B. and Durston, A. (2020), "Remote work-integrated learning experiences: student perceptions", International Journal of Work-Integrated Learning, Vol. 21 No. 4, pp. 401-414.

Ragusa, A.T. (2017), "Technologically-mediated communication: student expectations and experiences in a FOMO society", International Journal of Educational Technology in Higher Education, Vol. 14 No. 1, p. 39, doi: 10.1186/s41239-017-0077-7.

Ruggiero, D. and Boehm, J. (2016), "Design and development of a learning design virtual internship program", International Review of Research in Open and Distributed Learning, Vol. 17 No. 4, pp. 105-120, doi: 10.19173/irrodl.v17i4.2385.

Salas-Provance, M.B., Arriola, M.E. and Arrunátegui, P.M.T. (2020), "Managing in a crisis: American and Peruvian professionals' experiences during COVID-19", Perspectives of the ASHA Special Interest Groups, Vol. 5 No. 6, pp. 1785-1788.

Silva, P., Lopes, B., Costa, M., Melo, A.I., Dias, G.P., Brito, E. and Seabra, D. (2018), “The million-dollar question: can internships boost employment?", Studies in Higher Education, Vol. 43 No. 1, pp. 2-21, doi: 10.1080/03075079.2016.1144181.

Sias, P.M., Pedersen, H., Gallagher, E.B. and Kopaneva, I. (2012), "Workplace friendship on the electronically connected organization", Human Communication Research, Vol. 38, pp. 253-279, doi: 10.1111/j.1468-2958.2012.01428.x.

Solangi, A.F., Ahmed, M.U., Hussain, S. and Khattak, M.D. (2017), "Exploring the potential of virtual learning in an open and distance learning (ODL) environment", Pakistan Journal of Distance and Online Learning, Vol. 3 No. 1, pp. 9-22.

Stewart, C., Wall, A. and Marciniec, S. (2016), "Mixed signals: do college graduates have the soft skills that employers want?", Competition Forum, Vol. 14 No. 2, p. 276.

Sykes, D.M. and Roy, J. (2017), "A review of internship opportunities in online learning: building a new conceptual framework for a self-regulated internship in hospitality", International Journal of E-Learning and Distance Education, Vol. 32 No. 1, pp. 1-17.

Tan, C. (2018), Comparing High-Performing Education Systems: Understanding Singapore, Shanghai, and Hong Kong, Routledge, Abingdon and New York.

Tran, T.T. (2013), "Is the learning approach of students from the Confucian heritage culture problematic?", Educational Research for Policy and Practice, Vol. 12 No. 1, pp. 57-65, doi: 10. 1007/s10671-012-9131-3.

Van Dorp, C.A. (Ed.) (2008), Stimulating European Employability through Cross Sector Virtual Mobility: European Funded Research on Flexible Modality Internships, European Association of Distance Teaching Universities, Maastricht.

The impact of COVID-19 on internships 
HESWBL Waber, B.N. (2013), People Analytics, Pearson Education, Upper Saddle River, New Jersey, NJ.

12,3

Wall, K. (2020), "COVID-19 Pandemic: impacts on the work placements of postsecondary students in Canada", available at: https://files.eric.ed.gov/fulltext/ED605407.pdf (accessed 2 November 2020).

Wang, B., Liu, Y., Qian, J. and Parker, S.K. (2020), "Achieving effective remote working during the COVID-19 pandemic: a work design perspective”, Applied Psychology, Vol. 70 No. 1, pp. 16-59, doi: 10.1111/apps.12290.

Warr, P. (1994), "A conceptual framework for the study of work and mental health", Work and Stress, Vol. 8 No. 2, pp. 84-97, doi: 10.1080/02678379408259982.

Worthington, E.L. and Roehlke, H.J. (1979), "Effective supervision as perceived by beginning counselors-in-training”, Journal of Counseling Psychology, Vol. 26 No. 1, pp. 64-73, doi: 10.1037/ 0022-0167.26.1.64.

Yardley, S., Teunissen, P.W. and Dornan, T. (2012), "Experiential learning: transforming theory into practice", Medical Teacher, Vol. 34 No. 2, pp. 161-164, doi: 10.3109/0142159X.2012.643264.

\section{Corresponding author}

Cecilia Woon Chien Teng can be contacted at: ephtwcc@nus.edu.sg

For instructions on how to order reprints of this article, please visit our website: 